\title{
The Tryptophan Gene Cluster of Staphylococcus aureus
}

\author{
By A. R. PROCTOR AND W. E. KLOOS \\ Department of Genetics, North Carolina State University, \\ Raleigh, North Carolina 27607, U.S.A.
}

(Accepted for publication 24 October 1970)

\begin{abstract}
SUMMARY
Tryptophan auxotrophs were isolated from Staphylococcus aureus strain 655 following mutagenesis with ultraviolet radiation, $N$-methyl- $N^{\prime}$-nitro- $N$ nitrosoguanidine or ethyl methanesulphonate. The mutants were placed in five mutant classes on the basis of auxotrophic response to and accumulations of tryptophan intermediates or derivatives. The tryptophan loci were mapped by comparing relative distances of each locus from two reference loci, $\operatorname{tr} p B$ and $\operatorname{trp} E$. Relative distances of loci were determined by ratio test analysis of cotransduction data. The tryptophan loci were shown to be contained on a cluster on the $S$. aureus genome; the mapping data suggested the gene order: $\operatorname{trp} E, \operatorname{trp}(D F), \operatorname{trp} C, \operatorname{trp}(D F), \operatorname{trp} B, \operatorname{trp} A$. The genetically distinct $\operatorname{trp}(D F)$ regions presumably control two enzymic functions in the conversion of anthranilic acid to I-(o-carboxyphenylamino)-I-deoxyribulose 5-phosphate.
\end{abstract}

\section{INTRODUCTION}

The loci governing tryptophan biosynthesis are clustered and have similar arrangements in several members of the order Eubacteriales: Escherichia coli (Yanofsky \& Lennox, 1959; Smith, 1967), Salmonella typhimurium (Blume \& Balbinder, 1966); and Bacillus subtilis (Carlton \& Whitt, 1969). The tryptophan loci of Pseudomonas putida (Gunsalus et al. 1968) are located in three separate linkage groups. In the more highly evolved fungi, the tryptophan loci are unlinked (Bonner, DeMoss \& Mills, 1965; Mortimer \& Hawthorne, 1966; Hunter \& DeMoss, 1967; Roberts, 1967). These observations suggest that loss of clustering may be associated with evolutionary advancement. The conservation of genetic organization of tryptophan loci in species of the Eubacteriales lead us to surmise that tryptophan loci might be similarly arranged in other members of this order, especially those sharing a close evolutionary origin. The finding of a dissimilar arrangement would, following this hypothesis, constitute strong evidence of an evolutionary separation of the organisms considered. We have used this hypothesis to provide a comparison of the relatedness of two members of the order Eubacteriales, Staphylococcus aureus and Micrococcus luteus. These organisms are both members of the family Micrococcaceae, and have been the subject of much taxonomic debate (Baird-Parker, 1963). Though morphological similarities indicated a close relationship, modern taxonomic techniques have provided evidence of great dissimilarity in these organisms (Baird-Parker, 1963; Evans, 1965; Rosypal, Rosypalova \& Horejs, I966).

A study of the tryptophan loci of Micrococcus luteus was recently completed (Kloos \& Rose, 1970). A previous study of the tryptophan loci in Staphylococcus aureus by Ritz \& Baldwin (1962) showed linkage of ten tryptophan auxotrophs; however, their 
mutants were not characterized as to the specific genetic loci involved. The objective of the present study was to elucidate the genetic organization of the tryptophan loci in S. aureus.

\section{METHODS}

Bacterial strains. Staphylococcus aureus strain 655 was the source of all tryptophan auxotrophs used in this study. Salmonella typhimurium strain LT-2 tryptophan auxotrophs, $\operatorname{trp} C_{3}, \operatorname{trp} D_{10}, \operatorname{trp} B_{14}$ and $\operatorname{trpE268}$, were supplied by $\mathrm{Dr}$ E. Balbinder (Blume \& Balbinder, 1966).

Media. Dehydrated media, Brain Heart Infusion (BHI) agar and Trypticase Soy Agar (TSA), were obtained from Difco. P agar and P and D broth were prepared as described by Naylor \& Burgi (1956) and Pattee \& Baldwin (196I), respectively. The defined medium (S broth), used for growth of Staphylococcus aureus mutants, was a modification (omission of tryptophan) of that described by Kloos \& Pattee (1965a). The S agar was prepared by the addition of $\mathrm{I} \cdot 5 \%(\mathrm{w} / \mathrm{v})$ Special Noble agar (Difco) to $\mathrm{S}$ broth. The following modifications of S broth were used: ST broth (20 $\mu \mathrm{g}$. tryptophan/ $\mathrm{ml}$.); SI broth (20 $\mu \mathrm{g}$. indole $/ \mathrm{ml}$.; and SA broth $(20 \mu \mathrm{g}$. anthranilic acid $/ \mathrm{ml}$.) A second medium, the glucose salts medium of Davis \& Demerec as described by Lederberg (1950), was used for liquid culture of Salmonella typhimurium mutants.

Growth conditions. All cultures were grown at $37^{\circ}$, and liquid cultures were shaken either on a Burrell Wrist-Action shaker with cultures mounted over water baths, or on a rotary shaker (Fermentation Design, Inc., Allentown, Pennsylvania) housed in a $37^{\circ}$ incubator.

Stock cultures of Staphylococcus aureus were maintained on BHI agar slopes in screw-capped tubes, and subcultures were maintained in cotton wool-plugged tubes. Culture transfers were incubated at $37^{\circ}$ for $12 \mathrm{~h}$. and stored at $4^{\circ}$. All experiments were made with I2- or I8-h. BHI agar slope cultures transferred from the subcultures. Salmonella typhimurium cultures were maintained in an identical manner on $\mathbf{P}$ agar slopes in cotton wool-plugged tubes.

Mutant isolation. Tryptophan auxotrophs were collected following mutagenesis of of Staphylococcus aureus in four separate experiments using the following protocol: (I) bacteria from a $\mathrm{I} 2 \mathrm{~h}$. BHI slope culture were suspended in $5 \mathrm{ml}$. of either $0.85 \%$ $(\mathrm{w} / \mathrm{v}) \mathrm{NaCl}$ or sodium citrate; (2) mutagenesis by (a) irradiation $(90 \mathrm{sec}$.) of bacterial suspension in an open agitated Petri dish at a distance of $39 \mathrm{~cm}$. from a 'Mineralight Ultraviolet Lamp', Short Wave UVS-I I (II5 V, 0.I2 A) (Ultraviolet Products, Inc., San Gabriel, California); (b) incubation of bacteria in sodium citrate +50 or $100 \mu \mathrm{g} . / \mathrm{ml}$. $N$-methyl- $N^{\prime}$-nitro- $N$-nitrosoguanidine (NTG; $\mathrm{K}$ and $\mathrm{K}$ Laboratories, Inc., Plainview, New York) for I h. at $37^{\circ}$ (Adelberg, Mandel \& Chen, I965); (c) incubation of bacteria in $0 . \mathrm{I}$ M-potassium phosphate buffer $\mathrm{pH} 7 \cdot 0+0.4 \mathrm{M}$-ethyl methanesulphonate (EMS; Eastman Organic Chemicals, Rochester, New York) for $20 \mathrm{~min}$. at $35^{\circ}$ (Loveless \& Howarth, 1959); (3) the treated bacteria were washed free from chemical mutagens and suspended in $5 \mathrm{ml}$. of P and D broth; (4) the broth suspension was shaken at a setting of three (Burrell Wrist-Action Shaker) for $5 \mathrm{~h}$. at $37^{\circ}$, the organisms washed once in saline, and suspended in $10 \mathrm{ml}$. of $\mathrm{S}$ broth containing penicillin $\mathrm{G}$ (I unit/ml.; Calbiochem, Los Angles, California; Davis, 1949; Lederberg, I950); (5) the culture was grown in the penicillin-containing broth for $26 \mathrm{~h}$., the organisms washed, suspended in $\mathrm{P}$ and $\mathrm{D}$ broth, and stored at $4^{\circ}$ while the titre of viable bacteria 
was determined (growth in penicillin-broth was omitted from the experiment involving $50 \mu \mathrm{g}$. NTG $/ \mathrm{ml}$.); (6) samples of the stored bacterial suspension (diluted to produce 250 colonies per plate) were plated on 100 TSA plates; $(7)$ mutant clones were selected following replica plating (Lederberg \& Lederberg, 1952) to S agar and ST agar plates; (8) suspected mutants were streaked for isolation on TSA plates.

Mutant characterization and designation. All suspected mutant cultures were tested for response to tryptophan. Approximately $10^{9}$ bacteria from $\mathrm{I} 8 \mathrm{~h}$. BHI agar slope cultures were spread on $\mathrm{S}$ agar plates, and a few crystals of tryptophan added at one side of each plate. Evidence of auxotrophic response to tryptophan was recorded after incubation for $48 \mathrm{~h}$. The growth response of each tryptophan auxotroph to anthranilic acid and indole was determined by the same auxanographic technique.

To gain information about the tryptophan biosynthetic pathway of Staphylococcus aureus, and to characterize the biosynthetic block present in each mutant, de-repressed liquid cultures were examined for accumulations of known tryptophan biosynthetic intermediates and dephosphorylated derivatives. S broth supplemented with $2 \mu \mathrm{g}$. tryptophan $/ \mathrm{ml}$. ( $100 \mathrm{ml}$. in a $250 \mathrm{ml}$. Erlenmeyer flask) was inoculated to about $10^{7}$ bacterial $/ \mathrm{ml}$. with bacteria from $\mathrm{I} 8 \mathrm{~h}$. ST broth cultures of each mutant strain. These cultures were incubated for 4 days with rotary shaking $\left(250 \mathrm{rev} . / \mathrm{min}\right.$.) at $37^{\circ}$. Bacteria were removed by centrifugation and the culture supernatant fluids acidified to $\mathrm{pH} 5.0$ with $2 \mathrm{~N}-\mathrm{HCl}$. Tryptophan biosynthetic intermediates were extracted from the acidified supernatant fluids by shaking for $\mathrm{I} h$. with an equal volume of ethyl acetate. The ethyl acetate extract was decanted and reduced to a volume of $0.3 \mathrm{ml}$. by forced aeration. The concentrated extracts were chromatographed on Whatman no. I filter paper by development with methanol + ethyl acetate + water (I+2+ I, by vol.) $0.005 \mathrm{~N}$ in $\mathrm{NH}_{4} \mathrm{OH}$ (Yanofsky, 1956). The chromatograms were dried at room temperature, and examined under short-wave ultraviolet radiation for the fluorescent compounds indole-3-glycerol (InG), anthranilic acid (AA) and I-(o-carboxyphenylamino)-I-deoxyribulose (CDR). Further identification of AA and CDR spots was made by spraying separate chromatograms with Ehrlich reagent and triphenyltetrazolium (Yanofsky, 1960). Identification of indole and indole-3-glycerol in culture supernatant fluids was also made by the colorimetric techniques of Yanofsky (I955, 1956). The accumulations from previously identified mutants of Salmonella typhimurium (Blume \& Balbinder, I966) were used as standards for AA, CDR and InG. These mutants were grown in the glucose salts medium of Davis \& Demerec (Lederberg, 1950) supplemented with $2 \mu \mathrm{g}$. tryptophan $/ \mathrm{ml}$.

Genetic locus designations were assigned to each mutant on the basis of auxotrophic tests and accumulation patterns as outlined in Table $\mathrm{I}$. The enzymic function presumed to be associated with each locus is shown in Fig. I.

Phage preparation. All transduction studies were made with phage 83 of the International Typing Series. Phage 83 was propagated and titrated on various mutant strains by a modification (Pattee \& Baldwin, 196I) of the agar-overlayer technique of Swanstrom \& Adams (I95I). Filter sterilized lysates were stored at $4^{\circ}$ for periods up to 6 months.

Transduction techniques. All transduction experiments were made as described by Kloos \& Pattee (1965b) with the exception that various dilutions of the transduction mixtures were plated in accordance with the observed transducibility of the recipient strain used. 
The ratio test of Hartman, Loper \& Serman (1960) was used to test linkage of the tryptophan loci, and to determine the relative distance of markers from a nutritionally distinct locus within the cluster. Cotransduction data are used to determine relative distances of loci. The relative distance is expressed as $P$, the ratio of prototrophs to 'total' colonies (donor-type and prototrophic transductants). This ratio, $P$, corresponds to the probability of independent integration of the donor-marker into the recipient. The ratio test relies on the ability to distinguish prototrophic transductants from donor-type cotransductants. Prototrophic recombinants and donor-type recombinants form distinctly different colonies, large and small, respectively, on $\mathbf{S}$ agar plates; the donor-types are presumably fed by the recipient organisms on the plate. The number of donor-type cotransductants could also be determined by subtracting the number of prototrophs on $\mathrm{S}$ agar plates from the number of colonies (prototrophs and donortypes indistinguishable) on supplemented agar plates. Two such types of transduction schemes are possible with tryptophan mutants: crosses involving $\operatorname{trp} B$ recipients (growth on tryptophan only; accumulation of indole) with all other mutant classes (growing on indole) as donors; and crosses involving $\operatorname{trp} E$ mutants (growing on AA) as donors with all other mutant classes (not growing on AA; accumulating AA) as recipients. These two transduction schemes were used to determine the relative distance of all mutant classes to the $\operatorname{trp} B$ locus, and relative to the $\operatorname{trp} E$ locus. By determining the relative distance of each locus from two different loci, the order of the individual loci should be determined.

Transduced bacteria from each cross were spread on Io $\mathrm{S}$ agar plates to determine the numbers of both prototrophic and donor-type recombinants. In addition, transductants were spread on four supplemented agar plates: SI agar for crosses with $\operatorname{trp} B$

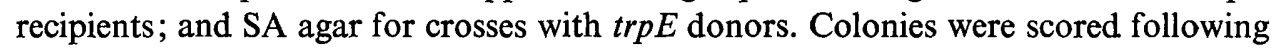
incubation for $72 \mathrm{~h}$. The value of $P$ was calculated from the total data from all 10 $\mathrm{S}$ agar plates for each cross. The data for 'total' colonies from the supplemented agar plates were used only when obvious discrepancies existed between the two sets of 'total' count data. This was observed when the donor-type colonies were poorly fed by the recipient background.

\section{RESULTS}

Mutant isolation and characterization. Two hundred and twenty-three tryptophan auxotrophs were isolated. Mutants $\operatorname{trp}-I$ through to $\operatorname{trp}-16$ were induced with ultraviolet radiation; mutants $\operatorname{trp}-17$ to $\operatorname{trp-203}$ with NTG; and mutants trp-203 to trp-2I9 with EMS. Mutants trp-220, -22I, -222, -223 were supplied as uncharacterized tryptophan mutants by Dr P. A. Pattee (Iowa State University), and represent mutants trp-I7, -20, -25, -26, respectively, of Dr Pattee's collection. Many of the mutants collected in this study had high reversion rates, were leaky, or had other growth abnormalities making them unsuitable for genetic analysis. These mutants were not further characterized. The remaining mutants were characterized in regard to their growth response to and accumulation of tryptophan biosynthetic intermediates. However, some of these mutants were eliminated from the study since they were unable to propagate phage 83 and/or be transduced. Table I lists mutants used in mapping experiments with the results of the biochemical characterizations, and the assigned genetic designations for each mutant. The pathway for tryptophan biosynthesis in Staphylococcus aureus (Fig. I) suggested by the accumulation patterns of the 
mutant classes was not shown to differ from the pathway occurring in other bacteria.

Cotransduction analysis. Phage 83 propagated on $\operatorname{trp} E$ donors gave donor-type transductants which were easily distinguishable from prototrophic colonies on $\mathrm{S}$ agar

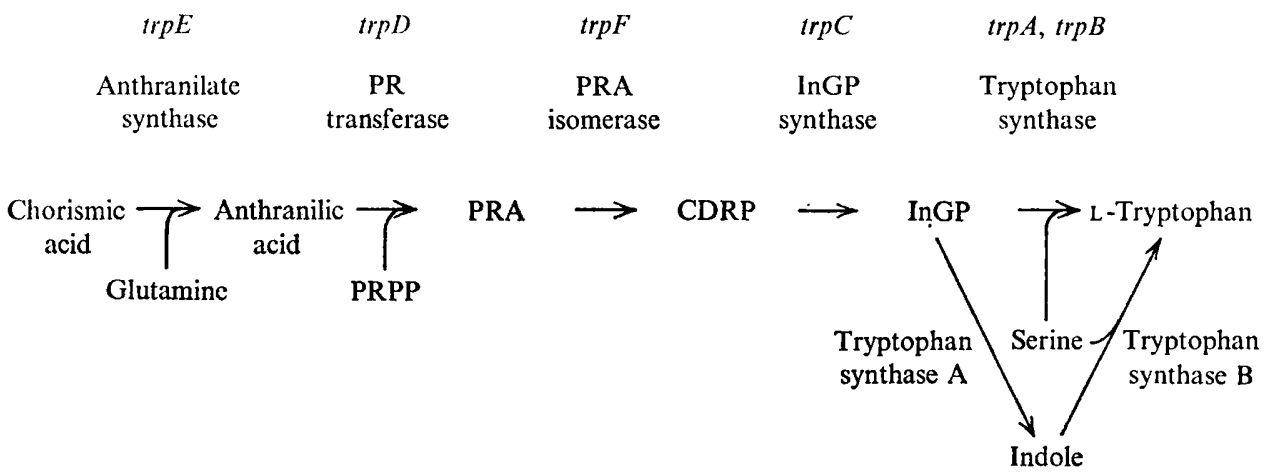

Fig. I. The tryptophan biosynthetic pathway of Staphylococcus aureus. Genetic loci and presumed enzymic functions are indicated above each step in the pathway. The classes $\operatorname{trp} D$ and $\operatorname{trp} F$ were not distinguished by biochemical characterizations, and all mutants which would presumably fall into these two categories were designated as $\operatorname{trp}(D F)$. PR transferase, anthranilate phosphoribosyl transferase; PRA isomerase, phosphoribosyl anthranilate isomerase; InGP synthase, indole-3-glycerol phosphate synthase; PRA, $N$-(5'-phosphoribosyl) anthranilic acid; CDRP, I-(o-carboxyphenylamino)-I-deoxyribulose 5-phosphate.

\section{Table I. Biochemical characterization and genetic designation of tryptophan auxotrophs of Staphylococcus aureus}

\begin{tabular}{|c|c|c|c|}
\hline $\begin{array}{l}\text { Genetic locus } \\
\text { designation }\end{array}$ & $\begin{array}{l}\text { Representative mutants } \\
\text { used in mapping }\end{array}$ & $\begin{array}{l}\text { Tryptophan intermediate } \\
\text { producing auxotrophic } \\
\text { response }\end{array}$ & $\begin{array}{l}\text { Tryptophan intermediate } \\
\text { accumulated in } \\
\text { de-repressed cultures }\end{array}$ \\
\hline $\operatorname{trp} E$ & $\begin{array}{l}78,85,125 \\
210,218,219\end{array}$ & $\begin{array}{l}\text { Anthranilic acid, } \\
\text { indole, and } \\
\text { L-tryptophan }\end{array}$ & None \\
\hline $\operatorname{trp}(D F)$ & $\begin{array}{l}3,155,170 \\
212,214,215\end{array}$ & $\begin{array}{l}\text { Indole or } \\
\text { L-tryptophan }\end{array}$ & Anthranilic acid \\
\hline $\operatorname{trp} C$ & $47,205,221$ & $\begin{array}{l}\text { Indole or } \\
\text { L-tryptophan }\end{array}$ & $\begin{array}{l}\mathrm{CDR}^{*} \text { and anthranilic } \\
\text { acid }\end{array}$ \\
\hline $\operatorname{trp} B$ & $26,207,223$ & L-Tryptophan & $\begin{array}{l}\text { Indole, InG, } \dagger \text { CDR, } \\
\text { and anthranilic acid }\end{array}$ \\
\hline $\operatorname{trp} A$ & $35,213,216$ & $\begin{array}{l}\text { Indole or } \\
\text { L-tryptophan }\end{array}$ & $\begin{array}{l}\text { InG, CDR, and } \\
\text { anthranilic acid }\end{array}$ \\
\hline
\end{tabular}

plates. Donor-type colonies were smaller in diameter: 0.2 to $\mathrm{I} \mathrm{mm}$. for donors, and I. 5 to $2.5 \mathrm{~mm}$. for prototrophs. In addition, pigment development was slower in donor-type colonies. Some of the morphologically distinguishable colonies were subcultured from crosses representing each locus and tested for the auxotrophic feeding pattern of the donor from that cross. These suspected donor-type cultures were also tested for failure to be transduced by the donor which produced them. Approximately $95 \%$ of the suspected donor types were confirmed. Cotransduction was observed 
between all $\operatorname{trp}$ loci; indicating linkage of all trp loci in a single transducing fragment of the Staphylococcus aureus genome. Ratio test analysis data are presented in Table 2 for $\operatorname{trp} E$ donor crosses and in Table 3 for $\operatorname{tr} p B$ recipient crosses. The relative distance of each mutant marker from the $\operatorname{trp} E$ locus and from the $\operatorname{trp} B$ locus is expressed as the probability of independent integration of $\operatorname{trp} E$ donor markers into recipient mutants, and as the probability of independent integration of different donor markers into $\operatorname{trp} B$ recipients. These data suggest the order: $\operatorname{trp} E, \operatorname{trp}(D F), \operatorname{trp} C, \operatorname{trp}(D F), \operatorname{trp} B, \operatorname{trp} A$ (Fig. 2). The average relative distance of each $\operatorname{trp}$ mutant from three reference $\operatorname{trp} E$ and $\operatorname{trp} B$ mutant sites is shown in Fig. 2. No significant gaps were observed in the $P$

Table 2. Ratio-test analysis of cotransduction from trpE donor crosses*

\begin{tabular}{|c|c|c|c|c|c|c|c|c|c|}
\hline \multirow{3}{*}{$\begin{array}{l}\text { Recipient } \\
\text { strain }\end{array}$} & \multicolumn{8}{|c|}{ Donor strain } & \\
\hline & \multicolumn{3}{|c|}{$\operatorname{trp} E 210$} & \multicolumn{3}{|c|}{$\operatorname{trpE2r8\dagger }$} & \multicolumn{3}{|c|}{$\operatorname{trp} E 219$} \\
\hline & Prototrophs & Total & $P \ddagger$ & Prototrophs & Total & $P$ & Prototrophs & Total & $P$ \\
\hline $\operatorname{trp} A 216$ & 3080 & 4419 & 0.70 & 2419 & 3776 & 0.64 & 2646 & 4019 & 0.65 \\
\hline $\operatorname{trp} A 2{ }_{3}$ & 2997 & 4853 & 0.62 & 1766 & 293 I & 0.60 & I 534 & 2738 & 0.56 \\
\hline $\operatorname{trp} B 223$ & 948 & I 599 & 0.59 & 727 & I I 8I & $0.6 \mathrm{I}$ & 2215 & 4313 & 0.51 \\
\hline $\operatorname{trpB207}$ & 2475 & 4402 & 0.56 & 2449 & 4352 & 0.56 & 2443 & 4959 & 0.49 \\
\hline $\operatorname{trp} B 26$ & 2588 & 6284 & $0.4 \mathrm{I}$ & 3249 & 6852 & 0.47 & I676 & 4419 & 0.38 \\
\hline $\operatorname{trp}(D F) I 70$ & II 84 & $324 I$ & 0.37 & 1146 & 2586 & 0.44 & 637 & 1930 & 0.33 \\
\hline $\operatorname{trp} C 22 I$ & 926 & 2684 & 0.35 & 1075 & 2721 & 0.40 & 671 & 2240 & 0.30 \\
\hline $\operatorname{trp} C_{47}$ & - & 一 & - & $5 \mathrm{I}$ & 235 & 0.22 & - & - & - \\
\hline $\operatorname{trpC205}$ & $6 \mathrm{II}$ & 2926 & $0.2 I$ & 533 & 2772 & 0.19 & 284 & 1503 & 0.19 \\
\hline $\operatorname{trp}(D F) 2 I 2$ & 1085 & 8282 & 0.13 & 548 & 6187 & 0.09 & 429 & 6340 & 0.07 \\
\hline $\operatorname{trp}(D F) 215$ & 147 & 3759 & 0.05 & 299 & 2788 & 0.11 & 1550 & I 1234 & 0.14 \\
\hline
\end{tabular}

* The transduction mixture consisting of recipient bacteria $\left(1 \cdot 2 \times 10^{10} / \mathrm{ml}\right.$.) and phage at a multiplicity of infection of three was incubated with shaking for $30 \mathrm{~min}$. at $37^{\circ}$ and centrifuged. The transduced bacteria were resuspended, diluted (about $10^{-1}$, varying with the recipient strain), and plated immediately.

$\dagger$ No cotransduction of the presumed unlinked markers, hisGIS and his $A I$, was observed with $\operatorname{trp} E 2 I 8$ and $\operatorname{trpA213.}$

$\ddagger$ The ratio of prototrophs to total (prototrophs and donor-type) transductants.

Table 3. Ratio-test analysis of cotransduction data from trpB recipient crosses

\begin{tabular}{|c|c|c|c|c|c|c|c|c|c|}
\hline \multirow{3}{*}{$\begin{array}{l}\text { Donor } \\
\text { strain }\end{array}$} & \multicolumn{9}{|c|}{ Recipient strain } \\
\hline & \multicolumn{3}{|c|}{$\operatorname{trpB} 207$} & \multicolumn{3}{|c|}{$\operatorname{trp} B 223$} & \multicolumn{3}{|c|}{$\operatorname{trp} B 26$} \\
\hline & Prototrophs & Total & $P^{*}$ & Prototrophs & Total & $P$ & Prototrophs & Total & $P$ \\
\hline $\operatorname{trp} A 216$ & 224 & 3030 & 0.07 & 295 & 2375 & 0.12 & 33 & 296 & 0.11 \\
\hline $\operatorname{trp} A 2 I 3$ & 246 & 3488 & 0.07 & $36 I$ & 2785 & 0.13 & 29 & 284 & $0 \cdot 10$ \\
\hline $\operatorname{trp} A 35$ & 169 & 3755 & 0.05 & 237 & 1707 & 0.14 & 48 & $26 I$ & 0.18 \\
\hline $\operatorname{trp}(D F) I 55$ & 346 & 3810 & 0.09 & 79 & 687 & 0.11 & 58 & 321 & 0.18 \\
\hline $\operatorname{trp}(D F)_{3}$ & 850 & 2292 & 0.37 & 317 & 2019 & 0.16 & 793 & 3455 & 0.23 \\
\hline $\operatorname{trp}(D F) r 70$ & 1162 & 3250 & 0.36 & 317 & 1766 & 0.18 & - & - & - \\
\hline $\operatorname{trp} C 221$ & 1320 & 3183 & $0.4 \mathrm{I}$ & 533 & 2230 & 0.24 & 67 & 307 & 0.22 \\
\hline $\operatorname{trpC205}$ & 1533 & 3923 & 0.39 & 893 & 2885 & 0.31 & $289 I$ & 6280 & 0.46 \\
\hline $\operatorname{trp} C 47$ & 676 & 1697 & 0.40 & 302 & 819 & 0.39 & 158 & 379 & 0.42 \\
\hline $\operatorname{trp}(D F) 214$ & 2314 & 4063 & 0.50 & 910 & 2160 & 0.42 & 137 & 336 & 0.41 \\
\hline $\operatorname{trp}(D F) 2 r 5$ & I 532 & 3555 & 0.43 & 733 & I 495 & 0.49 & 2559 & 5608 & 0.46 \\
\hline $\operatorname{trp} E I 25$ & 1933 & 3510 & 0.55 & 836 & 1663 & 0.50 & 2000 & 4259 & 0.46 \\
\hline $\operatorname{trp} E_{78}$ & 2890 & 4698 & 0.62 & 1109 & 2263 & 0.49 & 3164 & 6233 & $0.5 \mathrm{I}$ \\
\hline $\operatorname{trp} E 85$ & 1956 & 3146 & 0.62 & 691 & 1336 & 0.51 & 1934 & 3665 & 0.52 \\
\hline
\end{tabular}

* The ratio of prototrophs to total (prototrophs and donor-type) transductants. 
values from locus to locus. This is interpreted to mean that the tryptophan loci are contiguously clustered.

Abortive transduction analysis. We have been unable to find abortive transductants which would have been useful to identify mutant classes by complementation. The occurrence of tiny clones of stimulated mutant bacteria in the background growth of most mutant strains prevented the recognition of any such transductants. These clones occurred in controls with and without added phages at frequencies ten times that expected for abortive transductants; in general the ratio is about 5 to 20 abortive transductants to one complete transductant (Hayes, 1968). Mutant strains that were reisolated continued to exhibit this phenomenon.
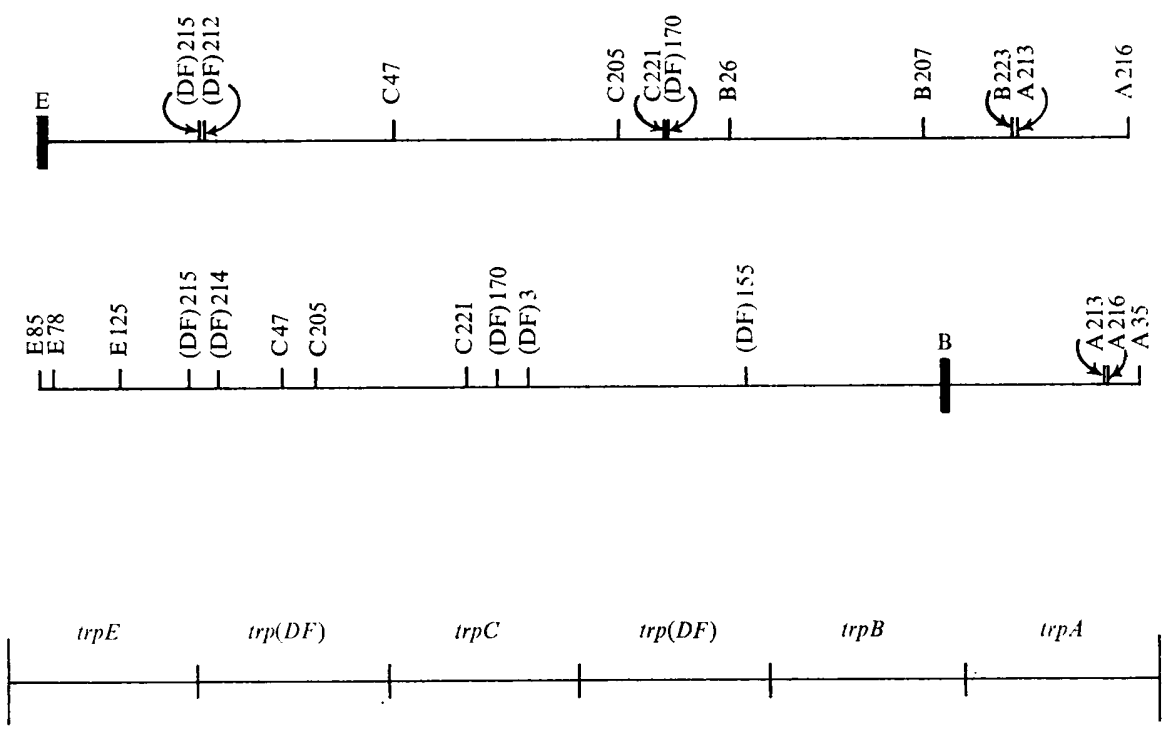

Fig. 2. The order of tryptophan loci in Staphylococcus aureus. The average relative distance of each $\operatorname{trp}$ mutant site from three reference $\operatorname{trp} E$ (designated E) and $\operatorname{trp} B$ (designated B) mutant sites is shown in the top two maps. The general map of the tryptophan cluster is diagrammed below.

\section{DISCUSSION}

The proposed map order of tryptophan loci is based on two-point mapping data and is therefore somewhat tentative. However, the ratio-test analysis used provides internal control against the ambiguity often associated with two-point mapping (Hartman et al. I960). Confirmation of this map order by deletion and/or three-point mapping would be desirable.

The apparent order of loci in the tryptophan gene cluster of Staphylococcus aureus is very similar to that of Escherichia coli, Salmonella typhimurium and Bacillus subtilis. This is yet another example of the similarity of this cluster in diverse members of the Eubacteriales. The gene order does not appear to be identical to that in S. typhimurium, for in this organism the tryptophan synthase $\mathrm{B}(\operatorname{trp} D)$ and the indole-3-glycerol phosphate synthase $(\operatorname{trp} E)$ functions are adjacent (Blume \& Balbinder, 1966). The order in $S$. aureus may be identical to that in the B. subtilis and $E$. coli clusters where the phosphoribosyl anthranilate isomerase $(\operatorname{trp} F$ and $\operatorname{trp} C$, respectively) function maps between the $\operatorname{trp} B$ locus and the indole glycerol phosphate synthase function(Smith, 1967; 
Carlton \& Whitt, 1969). However, the two $\operatorname{trp}(D F)$ loci in the $S$. aureus cluster were not defined, and a different order, $\operatorname{trp} E, \operatorname{trp} F, \operatorname{trp} C, \operatorname{trp} D, \operatorname{trp} B, \operatorname{trp} A$, may be correct.

An exception to this conserved pattern of $\operatorname{trp}$ loci in the eubacteria has been found by Kloos \& Rose (1970) in Micrococcus luteus. The order, $\operatorname{trp} E, \operatorname{trp} C, \operatorname{trp} B, \operatorname{trp} A$, common to all species of eubacteria examined, was retained; however, the $\operatorname{trp}(D F)$ function(s) were shown to be removed from the cluster. The results of the present study add significance to these findings.

Considering the similarity of the tryptophan gene clusters of organisms as diverse of Escherichia coli, Bacillus subtilis and Staphylococcus aureus, the failure of all the tryptophan loci to cluster in Micrococcus luteus is significant. This provides evidence of genetic dissimilarity of $S$. aureus and $M$. luteus. These genetic data further support the separation of staphylococci and micrococci by physiological criteria (Evans, Bradford \& Niven, I955; Baird-Parker, 1963), and by DNA base composition (micrococci 66 to $73 \%$ guanine + cytosine (GC), and staphylococci 30 to $36 \%$ GC, Rosypal et al. 1964). It is hoped that additional studies on the organization of other functionally related loci will prove helpful in further defining the relationship of these organisms.

The authors are indebted to Mrs Margaret Musselwhite for her excellent technical assistance. We wish also to thank Dr Robert Twarog for helpful suggestions regarding mutant characterization.

This work was supported by Research Grant AI-08255 from the Public Health Service. A. R. P. held a National Defense Education Act Title IV Graduate Fellowship.

This is paper number 3287 of the Journal Series of the North Carolina State University Agricultural Experiment Station, Raleigh, North Carolina.

\section{REFEREN CES}

Adelberg, E. A., Mandel, M. \& Chen, G. C. C. (1965). Optimal conditions for mutagenesis by $N$-methyl- $N^{\prime}$-nitro- $N$-nitrosoguanidine in Escherichia coli $\mathrm{K} 12$. Biochemical and Biophysical Research Communications 18, 788-795.

BAIRD-PARKER, A. C. (1963). A classification of micrococci and staphylococci based on physiological and biochemical tests. Journal of General Microbiology 30, 409-427.

Bonner, D. A., DeMoss, J. A. \& Mills, S. E. (1965). The evolution of an enzyme. In Evolving Genes and Proteins, pp. 305-31 8. Edited by V. Bryson \& H. J. Vogel. New York: Academic Press.

Blume, A. J. \& BalBINDER, E. (I966). Tryptophan operon of Salmonella typhimurium. Fine structure analysis by deletion mapping and abortive transduction. Genetics 53, 577-592.

CARLTON, B. C. \& WhITT, D. D. (I969). The isolation and genetic characterization of mutants of the tryptophan system of Bacillus subtilis. Genetics 62, 445-460.

DAvIs, B. D. (1949). The isolation of biochemically deficient mutants of bacteria by means of penicillin. Proceedings of the National Academy of Sciences of the United States of America 35, I-IO.

Evans, J. B. (1965). Current views and problems relating to the taxonomy of the Micrococcaceae. International Bulletin of Bacterial Nomenclature and Taxonomy 15, I I I-I I 2.

Evans, J. B., Bradford, W. L. \& Niven, C. F. (1955). Comments concerning the taxonomy of the genera Micrococcus and Staphylococcus. International Bulletin of Bacterial Nomenclature and Taxonomy 5, 61.

Gunsalus, I. C., Gunsalus, C. F., Chakrabarty, A. M., Sikes, S. \& Crawford, I. P. (I968). Fine structure mapping of the tryptophan genes in Pseudomonas putida. Genetics 60, 419-435.

Hartman, P. E., Loper, J. C. \& SeRMAN, D. (1960). Fine structure mapping by complete transduction between histidine-requiring Salmonella mutants. Journal of General Microbiology 22, 354-368.

HAYEs, W. (1968). The Genetics of Bacteria and Their Viruses, second edition, p. 642. New York: John Wiley and Sons, Inc. 
HuNTER, R. \& DeMoss, J. A. (1967). Organization of the tryptophan pathway: a phylogenetic study of the fungi. Journal of Bacteriology 94, 1 896-1907.

Kloos, W. E. \& Pattee, P. A. (1965a). A biochemical characterization of histidine-dependent mutants of Staphylococcus aureus. Journal of General Microbiology 39, 185-194.

KLoos, W. E. \& PATTEE, P. A. (1965b). Transduction analysis of the histidine region in Staphylococcus aureus. Journal of General Microbiology 39, 195-207.

KLoos, W. E. \& Rose, N.E. (1970). Transformation mapping of tryptophan loci in Micrococcus luteus. Genetics (In the Press).

LEDERBERG, J. (1950). Isolation and characterization of biochemical mutants of bacteria. Methods in Medical Research 3, 5-22.

LEDERBERG, J. \& LEDERBERG, E. M. (1952). Replica plating and indirect selection of bacterial mutants. Journal of Bacteriology 63, 399-406.

Loveless, A. \& HowARTH, S. (1959). Mutation of bacteria at high levels of survival by ethyl methane sulfonate. Nature, London 184, $1780-1782$.

Mortimer, R. K. \& HaWthorne, D. C. (1966). Genetic mapping in Saccharomyces. Genetics 53, $165-173$.

NAYLOR, H. B. \& BURGI, E. (1956). Observation on abortive infection of Micrococcus lysodeikticus with bacteriophage. Virology 2, 577-593.

Pattee, P. A. \& Baldwin, J. N. (196I). Transduction of resistance to chloretetracycline and novobiocin in Staphylococcus aureus. Journal of Bacteriology 82, 875 .

RITZ, H. L. \& BALDWIN, J. N. (1962). A transduction analysis of complex loci governing the synthesis of tryptophan by Staphylococcus aureus. Proceedings of the Society for Experimental Biology and Medicine 110, 667-67I.

ROBERTS, C. F. (1967). Complementation analysis of the tryptophan pathway in Aspergillus nidulans. Genetics 53, 233-239.

Rosypal, S., Rosypalova, A. \& HoRejs, J. (1966). The classification of micrococci and staphylococci based on their DNA base composition and Adansonian analysis. Journal of General Microbiology 44, $281-292$.

SмIтH, O. H. (1967). Structure of the $\operatorname{trp} C$ cistron specifying indoleglycerol phosphate synthetase, and its localization in the tryptophan operon of Escherichia coli. Genetics 57, 95-105.

Swanstrom, M. \& Adams, M. A. (1951). Agar layer method for production of higher titre phage stocks. Proceedings of the Society for Experimental Biology and Medicine 78, 372-375.

YANOFSKY, C. (1955). An isotopic study of the conversion of anthranilic acid to indole. Journal of Biological Chemistry 217, 345-354.

YANOFSKY, C. (1956). The enzymatic conversion of anthranilic acid to indole. Journal of Biological Chemistry 223, 171-184.

YANOFSKY, C. (1960). I-(o-carboxyphenylamino)-I-deoxyribulose 5-phosphate, a new intermediate in the biosynthesis of tryptophan. Journal of Biological Chemistry 235, $205 \mathrm{I}-2057$.

YANOFSKY, C. \& LENNOX, E. S. (I959). Transduction and recombination study of linkage relationships among the genes controlling tryptophan synthesis in Escherichia coli. Virology 8, 425-447. 